\title{
O ESTATUTO POLÍTICO DA DESOBEDIÊNCIA CIVIL NO PENSAMENTO DE HANNAH ARENDT
}

\section{THE POLITICAL STATUTE OF CIVIL DISOBEDIENCE IN HANNAH ARENDT'S THOUGHT}

\author{
Mário Sérgio de Oliveira Vaz. \\ Doutorando em Filosofia Pela Universidade Federal do Paraná - UFPR \\ mariovaz74@gmail.com
}

\begin{abstract}
RESUMO: Neste artigo, busca-se explicitar o estatuto político da desobediência civil no pensamento de Hannah Arendt. Para tanto, o texto se divide em três momentos: no primeiro momento, o objetivo é discorrer a respeito das potencialidades da desobediência civil, isto é, sua relação com o tema da liberdade e do poder. No segundo momento, discute-se a argumentação de Arendt com relação à pergunta pelo conceito de lei que possa ser mais apropriado com a desobediência civil e ressalta-se as implicações que o ato de desobedecer acarreta para a posição defendida pelos juristas diante do tema. E, por fim, o terceiro momento do artigo estabelece uma aproximação entre a noção de felicidade pública e a desobediência civil a fim de destacar como esse fenômeno cumpre um papel fundamental para o redescobrimento e atualização da relação entre liberdade, ação, poder e felicidade pública.
\end{abstract}

PALAVRAS-CHAVE: Desobediência civil. Ação. Poder. Liberdade. Felicidade pública.

ABSTRACT: This paper aims to make explicit the political statute of civil disobedience in Hannah Arendt's thought. To this end, the text is divided into three moments: in the first moment, the objective is to discuss the potential of civil disobedience, that is, its relation to the theme of freedom and power. The second moment concerns Arendt's argument regarding the concept of law that might be more appropriate with regard to civil disobedience and also the implications that the act of disobedience has for the position defended by jurists on the subject. Finally, the article establishes an approximation between the notion of public happiness and civil disobedience in order to highlight how this phenomenon plays a fundamental role in rediscovering and updating the relationship between freedom, action, power, and public happiness.

KEYWORDS: Civil disobedience. Action. Power. Freedom. Public Happiness.

\section{INTRODUÇÃO: A EFETIVIDADE DA DESOBEDIÊNCIA CIVIL}

A desobediência civil aparece quando um número significativo de cidadãos se convence de que, ou os canais normais para a mudança já não funcionam, e que as queixas não serão ouvidas nem terão qualquer efeito, ou então, pelo contrário, o governo está em vias de efetuar mudanças e se envolve e persiste em modos de agir cuja legalidade e constitucionalidade estão expostas a graves dúvidas (Hannah Arendt).

Uma das principais teses de Hannah Arendt contida em seu ensaio intitulado “Desobediência civil", presente no livro Crises da república (2004), é a de que o referido fenômeno não se reduz a objeção de consciência, tampouco encontra sua razão de ser na utilização da violência ( $C f$. ARENDT, 2004, p. 68). Com efeito, a desobediência civil, de acordo com Arendt, pressupõe a existência de um grupo que, via o agir em concerto, estabelece novas relações políticas, de modo que o referido fenômeno pode ser entendido como um potencial de ação capaz de resgatar a felicidade pública no interior das sociedades contemporâneas. Essa leitura pode ser percebida ao 
menos por dois aspectos fundamentais do texto de Arendt. O primeiro é a ênfase de sua argumentação no fato de que os desobedientes civis empreendem suas ações em conjunto e tornam públicas suas demandas por meio da comunicação entre seus membros e a sociedade ( $C f$. ARENDT, 2004, p. 69). Já o segundo aspecto diz respeito ao fato de que o horizonte de sentido que congrega os desobedientes ultrapassa a individualidade e o interesse particular de cada agente, posto que o dissentimento fundamental que os une, o desejo por mudança ou preservação do status quo $(C f$. ARENDT, 2004, p. 87-89), brota de um compromisso mútuo, e é este compromisso, de acordo com Arendt, que confere crédito e convicção às opiniões dos desobedientes.

Seguindo essas considerações, é possível ir ao encontro da interpretação proposta por Odílio Alves Aguiar (2011, p.124-125) segundo a qual a desobediência civil é imanente à teorização do poder em Hannah Arendt devido a sua inserção agônica no espaço público e por estar relacionada à tendência de inovar e instaurar novos espaços de liberdade no tecido da sociedade. Assim, a dinâmica da desobediência civil instaura um espaço no qual a decisão de se opor contra algum aspecto da política do governo pode se tornar efetiva, promovendo, assim, a reatualização do sentido de espaço público (entendido enquanto espaço de relação entre os cidadãos) e a efetivação da liberdade e o livre transcurso de opiniões, pois o próprio espaço público depende dessa constante atualização por meio da capacidade humana de agir e falar (Cf. ARENDT, 2010, p. 61). Ao se pautar pela participação dos cidadãos, a desobediência civil, longe de ser apenas uma perturbação da política comum, corresponde a um empreendimento coletivo que pode servir de iluminação para os tempos sombrios da política normatizada e uma força reatualizadora do poder constituinte.

Deste modo, por dizer respeito a uma atuação pública direcionada a um objetivo compartilhado pelos atuantes, pode-se avançar a partir da epígrafe trazida na abertura deste artigo, que o aparecimento da desobediência civil no interior de uma democracia estabelecida, é o sinal claro de uma resposta ex parte populi ${ }^{131}$ à determinadas situações em que, de um modo geral, (i) se desvela a coação organizada por parte do Estado, que se vale da institucionalização da violência e de outros dispositivos de domínio para se

\footnotetext{
131 Toma-se de empréstimo esta expressão de Celso Lafer que está presente em seu livro A reconstrução dos direitos humanos: Um diálogo com o pensamento de Hannah Arendt. Nele, escreve Lafer, que na análise dos processos de asserção e mudança dos direitos do homem na história, há: “[...] a perspectiva ex parte populi - a dos que estão submetidos ao poder - e a perspectiva ex parte principis - a dos que detêm o poder e buscam conservá-lo (1988, p. 125). Esta oposição também é utilizada por Lafer tanto em sua análise do aparecimento da violência na política quanto da desobediência civil, quando opõe a compreensão do direito de resistência pelo ângulo dos governantes a dos governos. Alguns elementos desta discussão serão apresentados no tópico seguinte.
} 
sustentar em sua ilegitimidade, (ii) quando as decisões governamentais são impulsionadas unilateralmente por interesses econômicos/privados ou puramente partidários, ou (iii) se percebe a não observância do princípio democrático da representação dos interesses da sociedade em nome da manutenção de uma organização burocrática e despolitizada.

No momento em que tais condições ${ }^{132}$ manifestam-se e um grupo decide empreender coletivamente ações e medidas essencialmente não violentas contra as mesmas, e que durante a sua atuação, associam-se com outras parcelas da sociedade, é que se pode falar, com propriedade conceitual, de um ato de desobediência civil. Com efeito, nas palavras de Arendt:

[...] a desobediência civil pode servir tanto para mudanças necessárias e desejadas do status quo - preservação dos direitos garantidos pela Primeira Emenda ou restauração do equilíbrio dos poderes do governo [...]. Em nenhum dos casos a desobediência civil pode ser comparada à desobediência criminosa [...]. De todos os meios que os contestadores civis possam lançar mão para a persuasão e para a dramatização dos problemas, o único que pode justificar a alcunha de 'rebeldes' é o meio da violência [...] e daí decorre que a 'desobediência civil não é revolução. O contestador civil aceita, enquanto o revolucionário rejeita, a estrutura da autoridade estabelecida e a legitimidade geral dos sistemas de leis (ARENDT, DC, 2004, p. 69-70 - Grifo meu).

Arendt propõe a hipótese de que os cidadãos recorrem à desobediência civil em momentos em que se constata a ineficiência das "vias normais" e dos instrumentos legais para que os governantes concedam atenção às suas objeções e queixas. Não se trata, portanto, de revolução, na medida em que os desobedientes não contestam a legitimidade do sistema jurídico e do sistema político da sociedade a que pertencem. Não se trata de mera rebeldia ou simples anarquismo, pois as ações praticadas pautamse pela não-violência (Ver LAFER, 1988, p. 233) e não procuram afirmar um interesse pessoal, mas sim exprimir um desacordo fundamental que é partilhado com outros indivíduos. Esse dissentir fundamental, antes de significar o desejo por destruição completa do poder e da autoridade estabelecida, corresponde a percepção da urgência de se lutar pela (i) preservação de direitos constituídos, mais especificamente, aqueles que dizem respeito a salvaguarda da liberdade de ação, isto é, do direito do povo, de forma pacifica, se reunir e se associar voluntariamente em torno de uma pauta estabelecida

\footnotetext{
${ }^{132}$ Cumpre destacar que os casos elencados acima são apenas algumas das muitas motivações possíveis para a ocorrência da desobediência civil. Não se trata, todavia, de uma classificação estanque, posto que uma das características mais elogiada por Arendt, no que se refere a ação em conjunto, é justamente seu caráter imprevisível.
} 
para fazer valer seus

direitos. ${ }^{133}$

Esta característica da desobediência civil é exemplarmente discutida por Arendt quando ela dirige sua atenção às liberdades garantidas pela Primeira Emenda e a conclusão levantada pela literatura acerca deste assunto segundo a qual se: "admite a necessidade desta ser "expandida" (Cf. ARENDT, 2004, p. 74) no sentido de abarcar positivamente em seu interior também o direito de divergir e não apenas a liberdade de expressão e de imprensa. Neste ponto, Arendt destaca o papel dos movimentos em torno dos direitos civis no contexto norte-americano, baseados na desobediência a uma "mais alta lei”, a saber, a Constituição, visando a efetivação das disposições presentes na $14^{\text {a }}$ Emenda, que tinha permanecido como letra morta por cerca de cem anos.

É por esse caminho que Arendt escreve que: “ [t] oda a substância da legislação trabalhista - o direito ao acordo salarial, o direito de se organizar e fazer greve - foi precedida por décadas de desobediência [...]" (ARENDT, 2004, p. 73). E Arendt acrescenta que não foram as leis, mas justamente atos de desobediência civil que trouxeram à luz a enormidade da escravidão ocorrida nos EUA, abrindo caminho para o devido reconhecimento desses acontecimentos. Ou seja, trata-se de perceber que por meio da desobediência civil é reestabelecida a coincidência fundamental entre a política, o agir e a liberdade no mundo público. O acontecimento político da desobediência está em consonância à compreensão de Arendt da política expressa em A condição humana (2010) entendida como relação, que se estabelece num intraespaço de convivência entre os indivíduos: "O domínio público, enquanto mundo comum, reúne-nos na companhia dos outros [...]" (ARENDT, 2010, p. 54). ${ }^{134}$ De modo que a desobediência civil surge, nesse sentido, como uma ilha de liberdade na qual o tesouro da felicidade pública é, mutatis mutandis, albergado, mais uma vez, na dimensão da ação humana.

A desobediência civil expõe ainda a necessidade de (ii) mudança: entendida aqui, num sentido específico, como reflexo de uma desaprovação diante de determinadas leis que não possuem, em si mesmas, um conteúdo legal objetivamente válido. Aqui, pode-

\footnotetext{
${ }^{133}$ Celso Lafer destaca que a ideia de Constituição em Hannah Arendt tem sua fonte de inspiração na experiência constitucional norte-americana, isso em razão de que, para ela: "[...] constituição significa "rule of law"; o direito de dissentir de indivíduos ou grupos como condição para tornar a promessa não apenas o resultado de um consentimento implícito, mas sim explícito - que desta maneira se estende no tempo - e também a plena aceitação, numa comunidade política, do Outro como semelhante" (LAFER, 1988, p. 230).

${ }^{134}$ Em sua apresentação de A condição humana, Adriano Correia comenta este aspecto relacional da política em Arendt nos seguintes termos: "A política surge no entre-os-homens; portanto, totalmente fora dos homens. Por conseguinte, não existe nenhuma substância política original" (CORREIA, p. XXXVII, 2010).
} 
se vislumbrar a desobediência civil diretamente articulada à afirmação do direito de resistência à opressão. O fulcro da questão, conforme destaca Celso Lafer, reside na ideia de uma reciprocidade de direitos e deveres, isto é: "se o legislador pode reivindicar o direito a ser obedecido, o cidadão pode igualmente reivindicar o direito a ser governado sabiamente e por leis justas" (LAFER, 1988, p. 188). Por isso, se num determinado governo, as leis mudam do dia para a noite e clamam por validade para toda espécie humana, e, por conseguinte, no corpo de suas leis vigentes: "estejam ausentes as características de estabilidade e de validade limitada - [...] estaremos nos confrontando com a ilegalidade" (ARENDT, 2004, p. 72). Nesses casos, de um modo geral, a mudança pretendida será sempre o resultado de uma ação extralegal que, segundo o entendimento de Lafer: "[...] exprime um poder novo, que está surgindo e que se volta para a mudança do status quo" (LAFER, 1988, p. 233). Isto é, embora a desobediência civil possa surgir na forma de uma contestação voluntária a uma determinada lei, ela tem o poder de tocar no fundamento da obrigação que leva à obediência ou à aceitação de uma norma, em consonância ao entendimento de que "o contrário da resistência é a obediência, o contrário da contestação é a aceitação" (BOBBIO, 2004, p. 152). De modo a esclarecer esta temática, na próxima seção avançase na discussão de como Arendt relaciona a desobediência civil com a questão do fundamento da lei, mostrando como a desobediência resgata a tradição das associações voluntárias.

\section{A RELAÇÃO ENTRE A DESOBEDIÊNCIA CIVIL E O ESPÍRITO DAS LEIS}

A perspectiva e mudanças muito rápidas sugere que há "toda probabilidade de ter a desobediencia civil um papel progressivamente expansivo nas... democracias modernas". Se a "desobediência civil chegou para ficar", como muitos vieram a acreditar, a questão de sua compatibilidade com a lei é da maior importância [...] (Hannah Arendt).

Hannah Arendt abre a última parte de seu ensaio refletindo sobre a relação entre o ímpeto por mudança e novidade "[...] inerente a um mundo habitado e estabelecido por seres humanos que nele chegam pelo nascimento como estrangeiros [...]" (ARENDT, 2004, p. 70) $)^{135}$ e a necessidade de estabilidade e conservação. Por essa via, Arendt

\footnotetext{
${ }^{135}$ Hannah Arendt ilustra sua afirmação ressaltando que: “[u]m alarmante sintoma desta reviravolta é a resoluta diminuição no intervalo entre as gerações. Do padrão tradicional de três ou quatro gerações por século, que correspondia a um hiato de gerações 'natural' entre pais e filhos, chegamos agora a um ponto em que quatro ou cinco anos de diferença na idade são suficientes para estabelecer um hiato entre as gerações" (ARENDT, 2004, p. 71). Com efeito, certamente esse assombro de Arendt esconde sua preocupação com a forma de lidar com o mundo que estas gerações irão engendrar. De tal forma que
} 
propõe uma discussão que se pontua pela seguinte pergunta: com que conceito de lei a desobediência civil é compatível? Nesse sentido, a autora recapitula que a lei, historicamente, é um dos fatores estabilizantes do fluxo de mudanças que ocorre no mundo humano, ou seja, os sistemas legais possibilitaram o abrigo para gerações sucessivas de indivíduos sob a Terra (Cf. ARENDT, 2004, p. 72). Tal fato é percebido na variedade de tais sistemas: seja a lex romana, o nómous grego e a torah hebraica. $\mathrm{O}$ que as reúne é o fato de que esses conjuntos foram planejados para assegurar certa estabilidade necessária para a duração no tempo de um determinado povo. Nesse sentido, as leis são aquilo que regulam nossas ações no mundo, delimitam nossas interações diárias e são "mais duradouros que modas, costumes e tradições (ARENDT, 2004, p. 72). Porém, as leis, deve-se dizer, não exprimem todo o conteúdo da política. Vale lembrar que em A condição humana Arendt compara as leis aos muros da polis, haja vista que elas cumprem a função de delimitar um espaço para a atuação e para o discurso (Ver ARENDT, 2010, p. 33, p. 219-240). Todavia, cumpre dizer que Arendt está se referindo a uma concepção geral de lei que confere aos cidadãos um estatuto jurídico fundamental de pertencimento a comunidade, a partir do qual a condição humana da pluralidade pode se efetivar no domínio público. É nesta mesma visada que Arendt ressalta a noção de pacto presente na base da lex romana e o caráter relacional do conceito de lei norte-americano. Em específico, o modelo norte-americano interessa à Arendt, pois ele se enraíza nas experiências coloniais associativas, de tal maneira que "a fonte e a função da lei não podem deixar de ser referidas ao poder político da comunidade" ( $C f$. ADVERSE, 2012, p. 429). Este último modelo será de grande valia para o argumento de Arendt que vincula a desobediência ao poder político.

Porém, conforme escreve Arendt, numa época de rápidas transformações, seria de suspeitar que as leis representariam: “[...] inevitavelmente uma 'força repressiva, e desta forma uma influência negativa' [...]" (ARENDT, 2004, p. 72). Mas seria possível dizer que o anseio por transformações cancelou a necessidade de estabilidade? Em consequência direta do desafio que representa a desobediência civil para a ordem legal, duas opções de leitura legalista assaltam o debate público, uma delas, no dizer de Arendt, propunha defender a existência de uma origem comum mais profunda que agregue num mesmo patamar rebeldes, revolucionários e desobedientes civis. A rigor, esta causa pode ser encontrada no desacordo para com o governo, que surge diante da mudança que não 
é aceita quando sugerida ex parte populi, ou que não deve ser cometida ex parte principis. Assim, assumindo que o sentimento particular de descontentamento e revolta seriam os contornos fundamentais da desobediência civil, chegar-se-ia à criminalização desses fenômenos sem operar as distinções cabíveis entre os mesmos.

Ora, acompanhando a argumentação de Arendt, encontra-se uma qualificação mais atenta e apropriada desse debate. Para autora, enquanto a violência se apoia progressivamente na efetividade de seus implementos técnicos, e depende sempre de uma justificativa para seu uso efetivo, a desobediência civil é um fenômeno que depende da concordância de muitos para vir a ser, de um acordo ou promessa mútua. Trata-se então do resgate e da afirmação da capacidade de ação, ancorada na comunicação entre os cidadãos atuantes, que constroem um espaço autônomo dentro da política normatizada. ${ }^{136}$ Em síntese, para dizer em consonância a Celso Lafer: "[...] a desobediência civil, sendo a expressão de um empenho político, não é a rejeição da obrigação política, mas a sua reafirmação” (LAFER, 1988, p. 234).

Outra alternativa considerada pelos juristas é apostar na ideia de que as mudanças alcançadas pela desobediência civil de forma sui generis, podem ser atingidas, de igual maneira, mediante a lei, isto é, no interior da própria constituição, no caso, a americana. A partir daqui a atenção de Arendt se dirige à reflexão acerca da pergunta pelo conceito de lei que possa ser mais apropriado com a desobediência civil e o papel que esse fenômeno desempenha nas democracias modernas. Certamente não se trata, para Arendt, de querer justificar pela lei o descumprimento da lei, pois a esse respeito ela é peremptória: “A lei realmente pode estabilizar e legalizar uma mudança já ocorrida, mas a mudança em si é sempre resultado de ação extralegal" (ARENDT, 2004, p. 73). Acerca desse ponto Arendt acrescenta o seguinte comentário:

Embora a desobediência civil seja compatível com o espírito das leis norte-americanas, as dificuldades em incorporá-la ao sistema legal norte-americano e justificá-la em termos puramente legais parecem ser proibitivos. Mas estas dificuldades decorrem da natureza da lei em geral

\footnotetext{
136 Esta tese é cara ao pensamento de Arendt e aparece formulada mais explicitamente em Sobre a violência nos seguintes termos: "É o apoio do povo que confere poder às instituições de um país, e este apoio não é mais do que a continuação do consentimento que trouxe as leis à existência" (ARENDT, 2011 , p. 35). Em outro momento deste mesmo ensaio Arendt escreve que por isso "[...] o governo é essencialmente poder organizado e institucionalizado" (ARENDT, 2011, p. 41). Já no ensaio sobre a desobediência civil, ao comentar a noção de lei norte-americana Arendt escreve que: “[...] a república norte-americana, repousa no poder do povo - o antigo potestas in populo de Roma - e poder confiado às autoridades é um poder delegado que pode ser revogado" (ARENDT, 2004, p. 77).
} 
e não do espírito especial do sistema legal norte-americano (ARENDT, 2004, p. 88).

Pelo conteúdo do excerto acima, compete então trazer a seguinte pergunta: qual é o modelo de lei - ou melhor, qual seu conceito fundamental - que possa albergar a desobediência civil, sem decorrer na ulterior punição ou criminalização do referido fenômeno. Deve-se dizer, antes de mais nada, que ao se mover nesse debate, Arendt não tinha por interesse discutir até que ponto a desobediência civil poderia ser melhor justificada legalmente pela Primeira Emenda ou pelos argumentos moralmente levantados e defendidos pelo indivíduo objetor. Não à toa, Arendt é crítica da leitura ofertada por Thoreau ${ }^{137}$ que circunscreve a desobediência "no campo da consciência individual" ( $C f$. ARENDT, 2004, p. 56). Seu interesse é prioritariamente as bases que fundamentam o dever de consentimento à lei em um contexto democrático, ou seja, numa sociedade de consentimento. Posto que, como Arendt registra em seu ensaio, a desobediência civil é uma tendência verificada primeiramente nos EUA e depois em outras partes do mundo, que tem por fundamento a afirmação da possibilidade de dissentir diante de um cenário de permissividade legal e de corrosão da autoridade instituída.

Desta forma, a autora se detém em mostrar como a concepção tradicional de lei e de obediência, mais especificamente as propostas de Kant e Rousseau ao problema do compromisso do indivíduo para com a lei são inapropriadas para esta discussão, posto que, para esses autores, sob o domínio da lei “[...] o homem não está sujeito a uma vontade alheia, está obedecendo a si mesmo - [...] é ao mesmo tempo seu próprio senhor e seu próprio escravo [...]” (ARENDT, 2004, p. 75-76). Frente a essa compreensão de aquiescência à lei, Hannah Arendt discorda de Rousseau e de Kant no tocante ao fundamento da obrigação política, qual seja, a auto obrigação determinada na consciência dos contratantes. Pois, para Arendt, esta relação do eu consigo mesmo não é suficiente para lidar com a pluralidade no âmbito da esfera pública $(C f$. LAFER, 1988, p. 228).

Ora, pode-se dizer que Arendt empenha-se em argumentar contrariamente à

${ }^{137}$ Hannah Arendt acrescenta em seu ensaio que o ato de desobedecer de Thoreau era limitado em seu alcance: “[...] o famoso ensaio nascido deste incidente e que tornou o termo 'desobediência civil' parte de nosso vocabulário político, debate sua causa não no campo da moral do cidadão em relação à lei, mas no campo da consciência individual e do compromisso moral da consciência [...] Thoreau não pretendia que o descomprometimento de um homem com o erro pudesse fazer o mundo melhor, ou que alguém tivesse qualquer obrigação de agir assim. [...] Aqui, como em toda parte, a consciência é apolítica. Não está primordialmente interessada no mundo" (ARENDT, 2004, p. 57-58). 
tese de que o indivíduo que pratica a desobediência civil, descumprindo uma disposição específica do ordenamento jurídico, estaria rompendo com o compromisso que o insere como componente da sociedade estabelecida e pelo qual se comprometeu a obedecer às leis. ${ }^{138}$ Para tanto, Arendt retoma a noção de consentimento na versão do: “[...] apoio ativo e participação contínua em todos os assuntos de interesse público [...]" (ARENDT, 2004, p. 76). O que Arendt pretende destacar é que só é possível falar em contrato vinculante do indivíduo com a sociedade em uma "versão horizontal", pois, a configuração deste modelo não se deve à submissão irrestrita da maioria a uma minoria, ou da outorga do poder popular a um representante ou a um soberano, mas antes, encontra suas bases no compartilhamento do poder com os outros, em uma comunidade fundada no princípio da liberdade entre iguais (Cf. ROVIELLO, 1987, p. 53).

Em diálogo direto com algumas das principais teses do contratualismo moderno, Hannah Arendt dá ênfase a versão horizontal do contrato apropriando-se dos elementos da teoria política de John Locke. ${ }^{139}$

A importância desta noção de pacto vinculante para o pensamento político de Arendt pode ser vislumbrada na dimensão da reciprocidade fundamental que, conforme Maria Cristina Müller, revela que aquilo que "une o povo nesta forma de governo são as promessas mútuas estabelecidas entre cada um dos cidadãos, independentemente da homogeneidade étnica, como no Estado-Nação, ou da intimidação [...]” (MÜLLER, 2016, p. 89). O foco é o estabelecimento de laços permanentes entre os seres humanos na tentativa de alcançar algumas garantias de estabilidade para o domínio público.

Essa "preferência" de Arendt por Locke justifica-se em sua intenção de endossar, sobretudo, o significado do consentimento enquanto participação voluntária numa societas na forma de uma aliança mútua entre todos os indivíduos. Em tal

\footnotetext{
${ }^{138}$ Sobre este ponto compete trazer o comentário de Helton Adverse que esclarece a relação da desobediência civil e o consentimento às leis: “[...] a ação de desobedecer tem imediatamente a lei por objeto, mas mediatamente concerne àquilo que a antecede e que está em sua origem: os princípios que animam o corpo político e o sistema de normas jurídicas que o organiza. Nesse sentido, a desobediência, ação necessariamente extralegal, como quer Arendt, jamais rompe com a legalidade” (ADVERSE, 2012, p. 426).

${ }^{139}$ Comentando essa "escolha” de Arendt por John Locke, Maria Cristina Müller traz que: "O consentimento se aproximaria da ideia do contrato social de Locke, em oposição àquilo que Arendt denomina de versão vertical do contrato social, que seria a ideia de contrato social de Hobbes. Arendt demonstra uma preferência pela versão lockeana, justificando-a pelas vantagens apresentadas por esse contrato. $\mathrm{O}$ tipo de reciprocidade em que se apoiam os participantes do contrato apresentado por Locke une cada um dos membros a um companheiro cidadão. Para Locke, o contrato limita o poder de cada indivíduo membro da sociedade, mas deixa intacto o poder da comunidade. O governo é estabelecido a partir do contrato original entre cada indivíduo independente [...]. Nestes termos, parece ser justamente a ideia de promessa mútua que leva Arendt a preferir Locke em detrimento de outros modelos. Com a ressalva de que a relevância não está no contrato, mas no consentimento entre os cidadãos" (MÜLLER, 2016, p. 89 - Grifo meu).
} 
configuração, os indivíduos depositam seu poder individual de maneira irreversível, mas encontram, na forma mesma desta concessão do poder, maneiras de manter sempre vivo o poder que amalgama o governo e anima as instituições em ações coletivas e de resistência, posto que, esse contrato:

[...] se apoia na reciprocidade, e a grande vantagem da versão horizontal do contrato é que esta reciprocidade liga cada um dos membros a seus colegas cidadãos. Esta é a única forma de governo em que o povo é mantido unido pela força de promessas mútuas e não por reminiscências históricas ou homogeneidade étnica (como no estado-nação) ou pelo Leviathan de Hobbes (ARENDT, 2004, p. 78).

Ora, sabe-se que todos nascem membros de uma determinada comunidade e só podem sobreviver se nela são bem recebidos e se sentem à vontade com as "regras diretivas e constitutivas" já existentes. De sorte que uma associação, firmada no princípio do consentimento, tem por base uma promessa mútua, estabelecida sob um poder horizontalmente distribuído, que implica uma pluralidade indissolúvel de homens e mulheres que assumem e reconhecem a forma deste pacto associativo. Isso equivale dizer que o compromisso para com a lei está intimamente ligado com a noção de liberdade. Por essa via, Arendt aponta que esta terceira variedade de convênio entre os cidadãos (em contraste ao convênio bíblico teocrático celebrado entre um povo e seu Deus e ao domínio do poder vertical do soberano sobre seus súditos na variante de Hobbes) é a versão que possibilita que seja preservado a independência dos espaços de poder no interior das formas instituídas de governo de acordo com a antiga noção do potestas in populo. Este poder, em última instância, emana da existência compartilhada dos cidadãos que, livremente, decidem reavivar o compromisso e as promessas nestas "ilhas de liberdade".

Compete ressaltar que Arendt não concebe esses elementos como ficções, presentes em uma narrativa acerca do aparecimento de comunidades políticas, haja vista que, para a autora, esta dupla disposição existencial de "dar e manter asseveração digna de confiança como sua conduta para o futuro" ( $C f$. ARENDT, 2004, p. 82) diz respeito ao "'espírito das leis', como Montesquieu o entendia, o princípio pelo qual as pessoas que vivem num determinado sistema legal agem e são inspiradas a agir” (ARENDT, 2004, p. 83). E foram experiências concretas como o Pacto do Mayflower e o estabelecimento das treze colônias que possibilitaram Arendt relacionar a desobediência civil diretamente à dynamis deste poder oriundo da reunião original que possibilita determinada comunidade 
organizar-se. Entende-se, desta forma, que a desobediência civil não pode dispensar um esclarecimento acerca da intrínseca relação entre o consentimento e o direito de divergir, porque:

[...] tornaram-se os princípios inspiradores e organizadores para ação, os quais ensinaram os habitantes deste continente a "arte de se associar uns com os outros [...]. Minha discussão é que os contestadores civis não são mais que a derradeira forma de associação voluntária [...] (ARENDT, 2004, p. 84-85).

Observa-se, assim, que para Arendt, a desobediência civil, tomada a partir de seu desenvolvimento, se constitui em consonância às prerrogativas das associações voluntárias tão elogiadas por Alexis de Tocqueville. O interesse da autora por esta experiência política gira em torno do fato de que o espaço de acontecimento da desobediência civil, originalmente erguido sob promessas mútuas sob o imperativo pacta sunt servanda ( $C f$. ARENDT, 2004, p. 86), possibilita a atualização da liberdade em um âmbito público politicamente instaurado. Assim pensada, a desobediência civil é um exemplo no qual a liberdade e o mundo público são como dois lados de uma mesma moeda. Nesse desobedecer, de acordo com Arendt, a ação coincide com a ideia de acordo, ou promessa, que compõe um dos momentos fundamentais da política, que leva à tomada de decisão e à ação em conjunto. Desta forma, as noções de pacto comum e reciprocidade, além de atuarem no fortalecimento do vínculo que mantém os membros de uma comunidade organizados ${ }^{140}$ surgem, para Arendt, como os critérios de legitimidade de atos públicos de dissentimento. Pois, o direito à contestação, ou melhor, a possibilidade de divergir não surge como um recurso externo ao espaço do político, mas aparece como uma decisão que é imanente à comunidade política.

Não obstante, se a desobediência civil é a expressão de um desacordo, ela é reveladora por excelência da ideia de que a lei não é aquilo que obriga, mas aquilo que possui a capacidade de reunir, de modo que, segundo Arendt: "quem sabe que pode divergir sabe também que de certo modo está consentindo quando não diverge" (ARENDT, 2004, p. 79). Em outros termos, indo de acordo com o que escreve Schütz e Vieira (2012, p. 25) no momento exato em que os movimentos de contestação surgem no horizonte das democracias consolidadas no sistema representativo, eles forçam a ampliação do horizonte político e, na medida em que são a prova viva de que a política

\footnotetext{
${ }^{140}$ Esta assertiva está alicerçada na tese de Arendt de que: "Toda organização de homens, seja social ou política, se baseia fundamentalmente na capacidade do homem de fazer e manter promessas e mantê-las. O único dever estritamente moral do cidadão é esta dupla disposição de dar e manter asseveração digna de confiança como sua conduta para o futuro [...]” (ARENDT, 2004, p. 82).
} 
e o seu significado precedem a noção de governo e de representação, forçam uma revisão dos sentidos destes campos.

Nos termos de Arendt, os contestadores representam a derradeira forma das associações voluntárias, que "não são partidos; são organizações ad hoc que perseguem objetivos a curto prazo e desaparecem quando o objetivo é atingido" (ARENDT, 2004, p. 84). No entanto, uma vez que a atuação em conjunto dos contestadores civis serve não apenas para publicizar demandas e reivindicações por reconhecimento, mas também para questionar os critérios de legitimidade que referendam as decisões políticas, discute-se, a seguir, a relação entre a desobediência civil e a felicidade pública.

\section{A DESOBEDIÊNCIA CIVIL E A FELICIDADE PÚBLICA}

Interessa agora discutir de que forma os movimentos de desobediência civil são capazes de reacender e manter viva a fata morgana da experiência política da felicidade pública no interior das democracias representativas. Essa questão, aparentemente simples em sua formulação, toca radicalmente em um problema, ao mesmo tempo, complexo e estruturante do pensamento político de Arendt, a saber, o problema do esquecimento do espírito revolucionário e a consequente redução do sentido da liberdade pública às liberdades civis e ao bem-estar econômico e individual dos cidadãos. ${ }^{141}$

À vista disso, percebe-se que decorre do debate e do diagnóstico sobre as experiências revolucionárias olvidadas e a ausência de um lugar instituído e apropriado para o devido exercício e a renovação daquelas qualidades que haviam servido para a edificação da república norte-americana, o teor severamente pessimista com que Arendt encaminha o encerramento de seu ensaio sobre a desobediência civil e que baliza sua descrença com relação ao sistema representativo:

O próprio governo representativo está em crise hoje; em parte porque perdeu, com o decorrer do tempo, todas as praxes que permitiam a real participação dos cidadãos, e em parte porque sofre gravemente da

\footnotetext{
141 No ensaio intitulado "Revolução e liberdade" Arendt aprofunda esse debate, refletindo como essa oposição entre liberdades civis e a liberdade pública, surgiu nos primeiros momentos da Revolução Americana e foi determinante para o seu decurso e para o desfecho da mesma no estabelecimento de uma Constitutio Libertatis: "Primeiramente, era uma questão de liberdade política, e não de direitos e liberdades civis, os quais poderiam ser obtidos através do estabelecimento de uma monarquia constitucional - uma possibilidade que, de fato, foi objeto de reflexões e, em seguida, rejeitada, precisamente porque não teria permitido aos cidadãos participarem do domínio público" (ARENDT, 2018, p. 198).
} 
mesma doença que o sistema de partidos: burocratização e tendência do bipartidarismo em não representar ninguém exceto as máquinas dos partidos (ARENDT, 2004, p. 79).

Por meio da passagem acima, Arendt deixa explicitamente clara sua percepção crítica do declínio da esfera pública nas sociedades contemporâneas, limitadas a uma insuficiente representação atingida pelo mecanismo do voto e que, geralmente, ilustram a transformação da política em administração de questões sociais ou de interesses privados. Assim, o que resulta disso é a ausência da possibilidade da política. Pode-se entender que esse encolhimento das possibilidades de participação ativa na res publica é reflexo do gradual esquecimento do vínculo originário entre liberdade e exercício político dos cidadãos no interior das democracias modernas ou, como Arendt designa em Da revolução (1990) as "democracias representativas." Ora, por entender que esse esquecimento da faculdade do agir, e de sua potencialidade de fazer surgir novos espaços de liberdade e novas formas de participação (Cf. DUARTE, 2016, p. 25), é resultante do intrincado sistema burocrático que compõe os Estados modernos.

Ademais, é essa reflexão que leva Arendt a concluir que a democracia representativa, e o sistema de partidos, é incapaz de albergar eventos extraordinários e imprevisíveis de atuação política. Isso sem considerar que o modelo representativo estabelece, via de regra, sua dinâmica e razão de ser exclusivamente com a esfera da sociedade e os interesses econômicos que a regem (Cf. GUERRA, 2013, p. 87), transformando, desta forma, o espaço público da deliberação em um local de negociações privadas entre os "representantes" de interesses parciais. Neste horizonte, o critério maior para justificar as decisões tomadas deixa de ser a legitimidade sustentada no poder e passa a ser a legalidade vazia de sentido político. Na esteira destas críticas de Arendt, é correto interpretar que está contida na ação uma pista sobre a questão do papel da desobediência civil e sua relação com o espaço público. Assim como a revolução, que possibilitou aos seus realizadores aventurarem-se em: "ações para as quais não tinham mostrado qualquer inclinação prévia" (ARENDT, 1990, p. 99), proporcionando aos seus atores o acesso à felicidade pública, a desobediência civil, por seu caráter extraordinário e imprevisível atua na reatualização dessa experiência fundamental.

No tocante a este ponto, Arendt escreve em sua resposta a Charles Frankel, ${ }^{142}$ que

${ }^{142}$ Este ensaio se faz presente na coletânea Ação e a busca pela felicidade publicada em 2018 pela editora Bazar do tempo. A versão traduzida foi extraída do livro Thinking without a banister: essays in understanding, 1953-1975 editado por Jerome Kohn. 
o direito de se reunir livremente ainda sobrevive nas associações voluntárias, das quais os grupos de desobediência civil da década de 1960 foram um exemplo notável, exemplificando, assim, as disposições fixadas na Primeira Emenda. Deste modo, sopesando as diferenças entre o pano de fundo das revoluções e as ações realizadas por seus atores (o rompimento e a fundação) e o background da desobediência civil (bem menos radical em suas aspirações), esses dois fenômenos extraordinários da política orbitam em torno da noção de felicidade pública. A desobediência civil, por estar ancorada em promessas e acordos que servem de parâmetros para o agir, e a revolução, entendida como o intento humano de estabelecer um novo espaço de liberdade (Constitutio Libertatis) a partir de um novo começo, são eventos em que a liberdade surge como uma experiência compartilhada, e a felicidade pública se efetiva na pluralidade do mundo. E por ser a liberdade o motivo que leva os homens a conviverem politicamente organizados (Cf. ARENDT, 2009, p. 191) e ultrapassarem a dimensão restrita da vida privada, a noção de felicidade pública compreende a acepção mais fundamental e viva desta palavra.

Por essa via, percebe-se que a liberdade pública é a conditio sine qua non do fenômeno da desobediência civil, pois os atos de desobediência manifestam, na política institucional, certo: "poder residual da revolução" na medida em que mantém vivo o espírito de resistência contra qualquer governo que tenha sido eleito ( $C f$. ARENDT, 1990, p.190). Há que se destacar ainda que com esta afirmação, Arendt não sugere que a desobediência cumpre unicamente o papel de subverter ou destruir o quadro político constitucional existente, isso porque, os atos de desobediência pressupõem direitos fundamentais estabelecidos para radicalizá-los além de sua jurisdição prescrita. Esses movimentos, através de suas lutas políticas, procuram aprofundar e expandir essas liberdades ( $C f$. KALYVAS, 2008, p. 291-292).

Com isso, a citação de Arendt acima deve ser interpretada no sentido de que a desobediência civil e, por conseguinte, a realização de sua felicidade pública, surge como um mecanismo ex parte populi de reanimação do poder constituinte, capaz de aproximar a política de sua origem constitucional e de sua base associativa, isto é, resgatando o espírito das associações voluntárias e dos conselhos participativos que estavam na base da República Americana. ${ }^{143}$

${ }^{143}$ A respeito da proximidade entre os atos de desobediência civil e os sistemas de conselhos Kalyvas escreve que: "Arendt's views on movements of civil disobedience could mediate between extraordinary and normal politics in a variety of ways. First of all, movements do not have the aristocratic, hierarchical, and elitist structures that councils do. They are free from the entanglements of representation. Likewise, 
Seguindo nessa discussão, é possível dizer ainda que é uma distinção da mesma ordem e grau que separa, por exemplo, a busca pela realização dos interesses privados e individuais, aquela que subjaz à oposição entre as associações de interesses dos grupos de pressão e as legítimas associações de contestação pública. Nesse último caso, Andreas Kalyvas (2008, p. 289) argumenta que os grupos de pressão, apesar da proximidade formal, representam uma degeneração da própria palavra associação, que passa a corresponder a organizações de interesses privados manifestos no âmbito público, visando a manipulação da opinião pública. ${ }^{144}$ Ainda de acordo com Kalyvas, enquanto os grupos de pressão baseiam-se no interesse, os desobedientes civis baseiamse em opiniões, que precisam ser formadas e compartilhadas por meio da discussão, do debate e da deliberação ( $C f$. KALYVAS, 2008, p. 289-290).

Essa capacidade de radicalização e a possibilidade de expansão do uso e da aplicabilidade de direitos e liberdades para esferas e campos que não estavam diretamente ou explicitamente prescritos no texto constitucional, mas que estavam implicados por sua origem revolucionária e desenvolvimento histórico, pode ser entendida como a realização da felicidade pública contida nos movimentos de desobediência civil. No caso da desobediência civil, portanto, o que está em jogo é a manifestação de um poder disruptivo e compartilhado, capaz de promover inovações dentro da estrutura jurídica por meio da ação em conjunto.

\section{REFERÊNCIAS}

ADVERSE, Helton. Arendt, a democracia e a desobediência civil. In: Revista Brasileira de Estudos Políticos | Belo Horizonte | n. 105 | pp. 409-434 | jul./dez. 2012.

AGUIAR, Odílio A. A dimensão constituinte do poder em Hannah Arendt. In: Trans/Form/Ação, Marília, v.34, n.1, p.115-130, 2011.

ARENDT, Hannah. Sobre a violência. $3^{\mathrm{a}}$ ed. Tradução de André de Macedo Duarte. Rio de Janeiro: Civilização Brasileira, 2011.

A condição humana. Tradução: Roberto Raposo, revisão técnica: Adriano Correia. - 11 ed. - Rio de Janeiro: Forense Universitária, 2010.

they operate apart from the existing mechanisms of organized power. They are based on the premise of a more direct, democratic form of participation, where citizens are able to speak and act for themselves" (KALYVAS, 2008, p. 289)

${ }^{144}$ Hannah Arendt em seu ensaio intitulado "Direitos públicos e interesses privados: uma resposta a Charles Frankel" escreve que: "A busca imprudente dos interesses privados na esfera política-pública é tão desastrosa para o bem público quanto as tentativas arrogantes dos governos de regular as vidas privadas de seus cidadãos o são para a felicidade privada" (ARENDT, 2018, p. 212-213). 
Entre o Passado e o Futuro. Tradução Mauro W. Barbosa. São Paulo: Perspectiva, $6^{\mathbf{a}}$ ed., 2009.

Da revolução. Tradução de Fernando Dídimo Vieira. Editora Ática e Editora da UnB, $2^{\text {a }}$ Ed., 1990.

Ação e a busca da felicidade. Organização e notas Heloisa Starling. Tradução de Virginia Starling. Rio de Janeiro: Bazar do Tempo, 2018.

. Crises da república. $2^{\mathrm{a}}$. ed. Trad. José Volkmann. São Paulo: Perspectiva, 2004.

BOBBIO, Norberto. A era dos direitos. Tradução de Carlos Nelson Coutinho; apresentação de Celso Lafer. - Nova ed., Rio de Janeiro: Elsevier, 2004.

DUARTE, André. Poder, violência e revolução no pensamento político de Hannah Arendt. In: Cadernos de filosofia alemã v. 21; n.3., pp.13-27. Dez. 2016 - Edição Especial - Dossiê Hannah Arendt.

GUERRA, Elizabete Olinda. Carl Schmitt e Hannah Arendt: olhares críticos sobre a política na modernidade. - São Paulo, LiberArs, 2013.

KALYVAS, Andreas. Democracy and the politics of the extraordinary. Max Weber, Carl Schmitt, and Hannah Arendt. Cambridge University Press, 2008.

LAFER, Celso. A reconstrução dos direitos humanos: Um diálogo com o pensamento de Hannah Arendt. São Paulo: Companhia das Letras, 1988.

MÜLLER, Maria Cristina. Política e governo são o mesmo? Uma reflexão a partir de Hannah Arendt. In: Cadernos de Ética e Filosofia Política, 1(28), 86-96. Disponível em ://www.revistas.usp.br/cefp/article/view/116272.

ROVIELLO, Anne-Marie. Senso comum e modernidade em Hannah Arendt. Tradução de João Filipe Marques. Instituto Piaget, 1987.

VIEIRA, Luis Vicente; SCHÜTZ, Rosalvo. Práxis filosófica: movimentos sociais em questão. Pelotas: Editora Universitária/UFPel, 2012.

Recebido em: 06/07/2020

Aceito para publicação em: 28/09/2020 